\title{
Sustainability Index Formulation of Soekarno Hatta Airport Railway Transport System
}

\author{
Firman Hamdani Kusumah ${ }^{1}$, Hayati Sari Hasibuan ${ }^{2}$, Ahyahudin Sodri ${ }^{3}$ \\ firmanhk@gmail.com $^{1}$, hayati.hasibuan@ui.ac.id ${ }^{2}$, ahya.sodri@gmail.com $^{3}$ \\ School of Environmental Science, Universitas Indonesia ${ }^{1,2,3}$
}

\begin{abstract}
Soekarno Hatta International Airport increased capacity requires good accessibility. To improve accessibility, the government built airport rail. However, the low level of occupancy threats the achievement of environmentally friendly advantages railway. This condition also affects the sustainability of the Soekarno Hatta Airport Rail. Therefore, it is necessary to know the level of sustainability of airport rail that suitable for developing country that have a limited capacity. This can be achieved by using sustainability transportation index with comparative study approach. Soekarno Hatta Airport Railway has lower sustainability compared to Hong Kong Airport Express and Narita Express. It is necessary to adjust the operation system based on occupancy level and to reduce travel time to improve its sustainability. Other policies that regulate travel behavior are needed so that the Soekarno Hatta Airport Rail will meet its purpose.
\end{abstract}

Keywords. Airport Rail, Sustainability Index, Soekarno Hatta Airport Rail.

\section{Introduction}

The high traffic of land transportation to Soekarno Hatta International Airport is not supported by an adequate transportation system. At major airports, passenger terminals are often problematic bottlenecks. The high traffic of people in airport became a problem of its congestion. This intermodal transportation requires to be treated as a continuous end-to-end process. This implies that problems arising either on the air- or the landside of an airport cannot be handled independently. Intermodal transportation can be a successful way to solve it [1]. Until 2017, the main access to Soekarno Hatta International Airport is only supported by road networks. The modal choice that rely only on road-based land transportation have low certainty of travel time depending on the level of traffic. rail systems offer better performance on speed, reliability, punctuality and comfort compared to other modes [1].

Along 2018 Soekarno Hatta Airport serves 68 million passengers and it targeted to serve 100 million passengers by 2025 . The increased capacity of Soekarno Hatta International Airport requires adequate accessibility support. It is estimated that the number of daily passengers is more than 160 thousand people per day. The existing road access only has a capacity of around 150 thousand vehicles and this can certainly be a problem. The airport buses passengers capacity is 38,000 passengers daily. This can be concluded that more than $70 \%$ passenger are using private/individual cars. To improve the accessibility of Soekarno Hatta International Airport, the government built airport rail. 
When transportation systems develop, integration between modes of transportation becomes a significant challenge for sustainable transportation. The integration between modes in the context of sustainable transport should be able to provide individual trip convenient, fast, efficient, secure and seamlessly, that will reducing the cost of switching modes (Zakowska, 2017). The expected vision for integrated transportation systems is that each mode of transportation plays its role at the best scale and operation (Reis et al., 2013).

One form of intermodal integration is air and rail integration. Integration between air transport and train services is defined as providing complete travel services with fast and smooth intermodal transfers (Givoni \& Banister, 2006). Integration between rail and air transportation has various types of benefits such as offering direct assistance to congestion problems, reducing negative environmental impacts, and increasing land-to-airport access (Cokasova, 2003). From the perspective of air transport service providers and airport managers, especially at airports with very dense flight schedules, the integration between trains and air transport will provide benefits in providing additional aircraft and passenger capacity, network benefits with higher service frequencies, and the reach of more and broader service goals [4]. The motivation of airports to integrate with railways comes from the desire for increased catch, enabling growth, reducing congestion, and attracting customer targets (Vespermann \& Wald, 2011).

Railway development has been seen as a promising strategy to achieve sustainable transportation especially low carbon emissions [6]. Advantages of carbon emissions from the rail compared to road and air transport can make important railway in sustainable transportation. Contributions train for sustainable transport depends on the share of each mode of transport, which is determined by the relationship between rail and other transport modes, including competition, cooperation, and integration (Li, 2014).

The formulation of this research problem is that the construction of the Soekarno Hatta Airport Railway initially aimed to provide public transportation to the airport that was efficient and environmentally friendly. However, because of the low operational effectiveness, the environmental, economic and social sustainability of these transportations is threatened because the resources that have been spent do not meet their objectives. Therefore, it is necessary to formulate a strategy to improve sustainability performance.

\section{Method}

This research uses quantitative methods with comparative study approaches. The method used is the Transport Sustainability Index. This method is used to analyze the indicators that are variable-forming sustainability that need to be improved to improve the performance of the Soekarno Hatta airport rail.

\section{Environment}

Sustainability of the environmental dimension is based on the principle of limiting emissions and waste, minimizing the consumption of both unrenewable and renewable resources, reuse and recycle components, and minimize land use and sound pollution production. The environment category has four sets of variables: energy use, pollution, and greenhouse gas emissions. 


\section{A. Energy consumption}

The energy consumption indicators are registered for use, which can be converted into energy values based either on the known fuel average energy content, or forecasts based on fuel standards. All energy indicators are considered negative impacts.

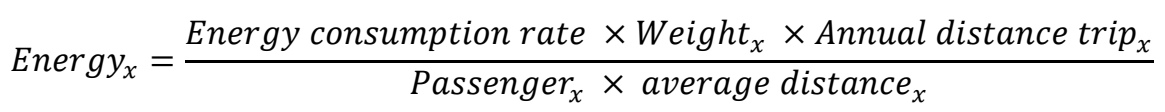

\section{B. Green House Gas}

Green House Gas (GHG) emissions represent the system's impact on global climate change through greenhouse effects. The GHG included in this methodology are: $\mathrm{CO}_{2}, \mathrm{CH}_{4}$, and $\mathrm{N}_{2} \mathrm{O}$. They are input as a single indicator equivalent to $\mathrm{CO}_{2}$. For this study, GHG issued during the construction of transportation systems has not been considered, but this can be included in future revisions through the inclusion of lifecycle methodologies. GHG emissions are calculated based on electricity emission factors for each location. All GRK indicators are considered negative impacts.

$G H G_{X}=$ Energy $_{X} \times$ Electricity rate $G H G$

C. Noise pollution

Set of pollution factor is noise indicator used is noise, data source can use data historical data or data model; However, the use of noise is difficult in high-level studies due to the data quality and the complexity of the analysis required. All pollution indicators are considered negative impacts. These noise pollution is obtained based on primary data measurements and secondary data for the comparison corridor.

\section{Economic}

The sustainability of economic aspect needs to be seen from the two perspectives, from the user side and from the operator side. The economic sustainability of each perspective can be defined as a comparison between the costs and benefits of Each perspective. Thus, the category of economics includes a set of variables related to the intensity of use towards system formation costs, the user's cost to the benefits of travel, and the comparison of revenue to the cost of the system. The principle of sustainability performance measurement in economic dimension, especially adhering to the criteria of cost efficiency, which refers to performance indicators comparing the quantity of services produced on resources (cost Effectiveness) criteria that refer to the performance indicators comparing the quantity of services consumed by the user to the resources used.

\section{A. User Cost}

User cost are an economic cost incurred for travel that accesses the system. In this study, costs were measured in time and money. Financial costs are represented as the average price a user pays per trip, and the time cost is represented by the average time spent on public transport by each user. All costs are negative inputs.

\section{a. Tariff Costs}




$$
\text { User } \text { Cost }_{x}=\frac{\text { Tariff }_{x}}{\text { Distance }_{x}}
$$

b. Time Cost

Time Cost $x=\frac{\text { time }_{x}}{\text { distance }_{x}}$

B. Operating income

a. Operating income Per operating cost

$$
\text { Operation } \text { margin }_{x}=\frac{\text { Operation } \text { Income }_{x}}{\text { Operation } \operatorname{Cost}_{x}}
$$

b. Operating costs per seating distances available

$$
\text { operation cost per seat distance available }_{x}=\frac{{\text { operation } \text { cost }_{x}}_{\text {Seat distance available }}}{\text { aval }_{\text {sila }}}
$$

c. Operating costs per train mileage

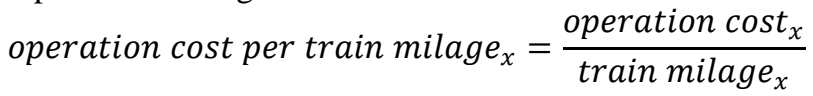

d. Operating income Per passenger mileage

$$
\text { operating income per passenger milage } e_{x}=\frac{\text { operating } \text { income }_{x}}{\text { passenger } \text { milage }_{x}}
$$

e. Operating income Per train mileage

$$
\text { operating income per train milage } e_{x}=\frac{\text { operating } \text { income }_{x}}{\text { train } \text { milage }_{x}}
$$

Sustainability performance of airport railroad social dimension

Social dimension sustainability performance is assessed based on usage intensity, affordability and service coverage.

A. Usage intensity

The intensity of use of the services in the analysis of the study consists of two indicators that are the passenger load capacity assessed from the comparison between the mileage of the passenger with the distance of the seat is available, and the second indicator is the mileage Passenger per vehicle mileage.

a. Passenger mileage Per Seat Available Kilometer

$$
\text { passenger milage per seat available } \text { kilometer }_{x}=\frac{{\text { Passenger } \text { milage }_{x}}_{\text {seat available } \text { kilometer }_{x}}}{\text { avilom }}
$$

b. Passenger mileage per train mileage

$$
{\text { Passengger } \text { milage }_{x}=\frac{\text { passengger } \text { milage }_{x}}{\text { rail milage }}}_{x}
$$

B. Affordability

$$
\text { affordability }_{x}=\frac{\text { tariff per } \mathrm{km}_{x}}{\text { Income per kapita }}
$$


C. Service coverage

$$
\text { Coverage }_{x}=\frac{\text { air passengger }}{\text { distance seat available }_{x}}
$$

D. Mode Share

$$
\text { Mode Share }_{x}=\frac{\text { rail passengger }}{\text { air passengger }}
$$

Normalization of Data

For indicators with positive impact

$$
n_{i}=\frac{x_{i}}{\operatorname{Max}(\text { all } x)}
$$

For indicators with negative impact

$$
n_{i}=\frac{\operatorname{Min}(\text { all } x)}{x_{i}}
$$

Where $\mathrm{n}$ is the value of indicator utility for each airport rail. The value of $\mathrm{n}$ will approach the value of 1 to indicate the highest performance route and will approach value 0 for the lowest performance route.

Strategy Analysis

To identify indicators who need to be improved, this research using gap analysis. The gap is the difference between Soekarno Hatta Airport rail link and the benchmark location. Every indicator then observed until its data level. Based on the data, possibility to interfere and its weight, the strategy can be estimated at best scenario.

\section{Result and Discussion}

The highest Gap is on an environmental indicator with a difference of 0.59 points and a social indicator with 0.58 points. If viewed in sub-level indicators then the highest gap is in share mode, greenhouse gas emissions, service coverage, energy, and usage intensity. The gap is far between 0.78 and 0.95 points where the biggest number is 1 . On the Sub indicator mode share, which causes the low score is inadequate number of passengers. The number of passengers is also the cause of low performance on energy consumption, greenhouse gas emissions, usage intensity. 
Table 1. Airport Rail Sustainability Index

\begin{tabular}{|c|c|c|c|c|}
\hline \multirow{2}{*}{$\begin{array}{l}\text { DIMENSIONS OF } \\
\text { SUSTAINABILITY }\end{array}$} & \multicolumn{4}{|c|}{ AIRPORT RAIL } \\
\hline & $\begin{array}{l}\text { Soekarno } \\
\text { Hatta }\end{array}$ & $\begin{array}{l}\text { Hong Kong } \\
\text { Express }\end{array}$ & Airport & $\begin{array}{l}\text { Narita } \\
\text { Express } \\
\end{array}$ \\
\hline Environment & 0,41 & & 0,79 & 1,00 \\
\hline Energy & 0,20 & & 0,82 & 1,00 \\
\hline Greenhouse gas & 0,10 & & 0,58 & 1,00 \\
\hline Noise & 0,93 & & 0,97 & 1,00 \\
\hline Economic & 0,64 & & 0,76 & 0,84 \\
\hline User costs & 0,73 & & 0,88 & 0,99 \\
\hline Tariff costs & 0,93 & & 0,77 & 1,00 \\
\hline Time cost & 0,54 & & 1,00 & 0,99 \\
\hline Operating income & 0,55 & & 0,63 & 0,69 \\
\hline Operating income Per operating cost & 0,32 & & 0,71 & 1,00 \\
\hline $\begin{array}{l}\text { Operating cost Per Seat distance } \\
\text { available }\end{array}$ & 1,00 & & 0,27 & 0,25 \\
\hline Operating costs per train mileage & 1,00 & & 0,16 & 0,23 \\
\hline $\begin{array}{l}\text { Operating income Per passenger } \\
\text { mileage }\end{array}$ & 0,35 & & 1,00 & 0,98 \\
\hline $\begin{array}{l}\text { Operating Income Per vehicle } \\
\text { mileage }\end{array}$ & 0,07 & & 1,00 & 0,97 \\
\hline Social & 0,33 & & 0,80 & 0,91 \\
\hline Usage Intensity & 0,22 & & 0,83 & 0,99 \\
\hline Intensity of seat spacing available & 0,22 & & 0,66 & 1,00 \\
\hline Intensity of the train mileage & 0,21 & & 1,00 & 0,99 \\
\hline Affordability & 0,93 & & 0,77 & 1,00 \\
\hline Service coverage & 0,13 & & 0,61 & 1,00 \\
\hline Mode share & 0,05 & & 1,00 & 0,65 \\
\hline
\end{tabular}

Source: secondary data output, 2019

Airport Rail link Soekarno Hatta have the lowest indices at all indicators. The indices gap shows that economic indicator is the better indices than environmental and social indicator. Based on all indices the lowest performance is the mode share, it shows that the level of utilization of airport rail is very low compared other two airport rail. It also shows that the airport rail underutilizes than other mode such as airport bus or private cars and taxi. 


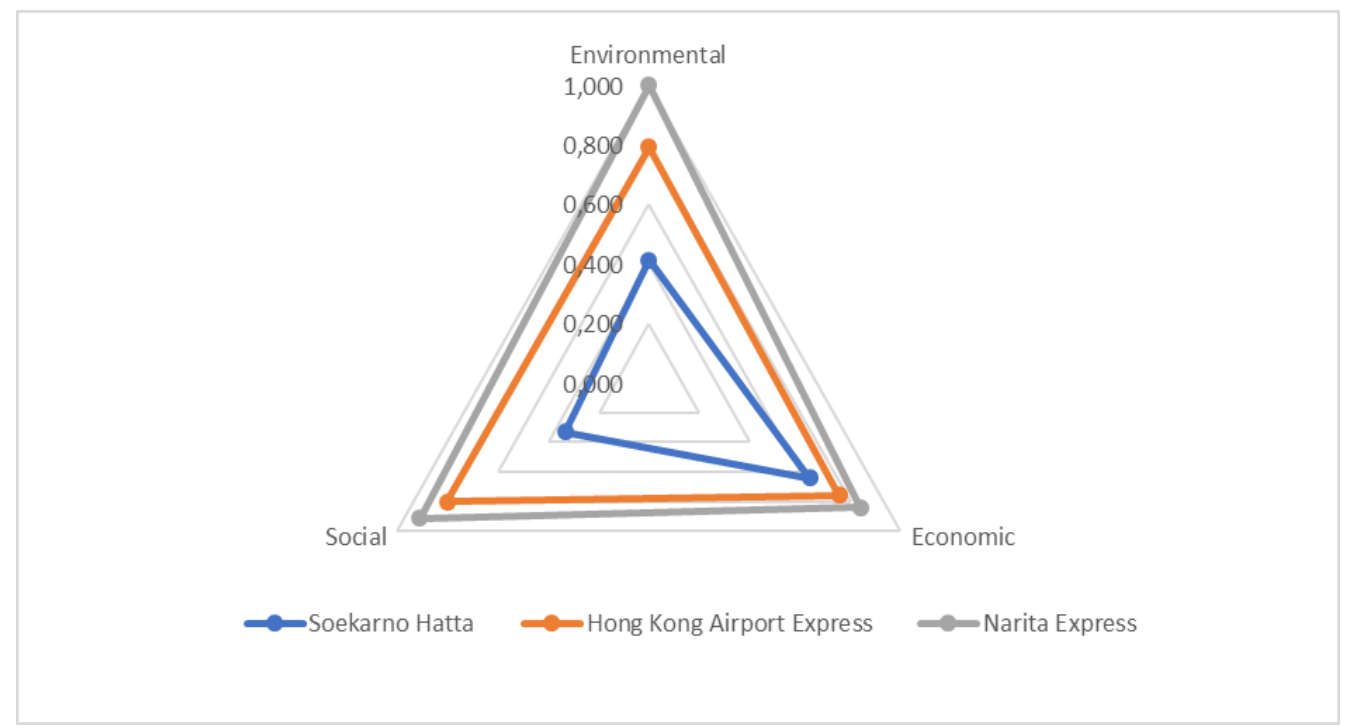

Figure 1. Sustainability Index of Soekarno Hatta Airport Rail, Narita Express and Hong Kong Airport Express

Narita Express have a better score at all indicators. Narita express have a best performance at all sub indicators. It is clear that both Narita Express and Hong Kong Airport Express have a good balance for each dimension of sustainability indices. In general, the Narita Express excels at all three dimensions followed by the Hong Kong Airport Express. If observed based on the relationship between dimensions of the pillars of sustainability, it can be known that the Soekarno-Hatta Airport rail tends to have environmental degradation and low social equity because it is focus more on economic than to the environment and social aspect. To improved its sustainability, Soekarno Hatta Airport rail should improve its performance on environmental and social dimension.

Indicators that can be improved to increase the level of sustainability are passenger numbers and the average distance of the journey. In short-term and only in response to the current low levels of utilization. Reduction in route distances and the number of trips per day have the highest weight by a total of 1,266 . However, for the route distance should also be noted for its influence on other indicators because the change of this indicator will have a double effect on the other indicators, with a ratio of 1.266 to 0.7 .

It is necessary to adjust the operating pattern based on the occupancy rate, so airport rail will be more effective and efficient. and improvement of the travel time to increase its sustainability. Need policy governing travel behavior so that the utility of Soekarno Hatta Airport will increase so that the destination of development can be achieved. 
Table 1. Data Indicator Influenced

\begin{tabular}{|c|c|c|c|}
\hline Data & $\begin{array}{l}\text { Number } \\
\text { of } \\
\text { indicators } \\
\text { influenced }\end{array}$ & $\begin{array}{l}\text { Weight of } \\
\text { Increased } \\
\text { indicators } \\
\text { influenced }\end{array}$ & $\begin{array}{l}\text { Weight of } \\
\text { Decreased } \\
\text { indicators } \\
\text { influenced }\end{array}$ \\
\hline Train Weight & 2 & 0 & 0.666 \\
\hline Operating Cost & 3 & 0 & 0.3 \\
\hline Average passenger milage & 5 & 0.916 & 0.1 \\
\hline Route Distance & 10 & 0.7 & 1.266 \\
\hline Annual air passenger & 2 & 0.25 & 0.25 \\
\hline Trip per day & 7 & 0.1 & 1.266 \\
\hline Seat capacity & 3 & 0.1 & 0.375 \\
\hline Noise & 1 & 0 & 0.333 \\
\hline Operating income & 3 & 0.3 & 0 \\
\hline Income per capita & 1 & 0.25 & 0 \\
\hline Passenger & 6 & 1.166 & 0.1 \\
\hline Tariff & 1 & 0 & 0.25 \\
\hline Travel Time & 1 & 0 & 0.25 \\
\hline
\end{tabular}

Sustainability improvement strategy is done by the Principles of efficiency and effectiveness. Improved sustainability is done by adding to the route that has large passenger potential and reduces travel that has low occupancy. In addition, improvements are made with improved connectivity and travel time so that passenger preferences using airport rail will increase.

To improve environmental dimension we can do it by increase its performance from data level. Energy and green house gas variabel are basicly comparison between energy usage and passenger milage. To improve its performance it can be done by lower the energy consumption by decrease the trip frequencies and/or to increase passenger number and its milage number. The decreasing of trip frequencies will lower the passenger number too, but in the final result if we delete trips that have passenger under daily average number, the efectivity of energy consumed and green house gas emmision still better in underutilze public transport. Delete ten trip on low peak hour can improve environmental indices by $3.75 \%$, economic indices $0.94 \%$ and social indices $1.20 \%$. For composite indices this strategy can improve the sustainability index by $1.83 \%$.

Passenger number or ridership were the main purpose of public transport achievement. Improvement of ridership level could increase the enviromental indices and also in economic and social indices. If the ridership increase $50 \%$, can improve environmental indices by $12.08 \%$, economic indices $3.02 \%$ and social indices $10.14 \%$. For composite indices this strategy can improve the sustainability index by $7.42 \%$. Improving ridership is not something that can be done directly. To obtain this goal it should be done by another strategy. Based on passenger preference two most important aspect are tariff and travel time. Increase travel time performance can be one of good strategy to be done. If we compare to Narita and Hong Kong, Soekarno Hatta 
Airport Rail performance are very low which is almost two times slower. To increase ridership it also can be done by increasing the conectivity of the station by built conectivity infrastructure or by using a feeder transportation to enlarge the service coverage.

Lower the train weight can be one option to improve its sustainability. What we can do to lower the train weight are to reduce the car number matched to the passenger number. This strategy already done by Narita Express by split it car number. Hal number of it take off from outside of Tokyo and then join with another half in Tokyo Station. This strategy related to future route improvement.

To build an integrated transportation system and strengthen each other, the operating pattern of both transport systems must be synergized. The adjustment between headway and flight schedule configuration needs to be done to make this transportation more reliable. In terms of schedules, travel is mainly focused on peak hours, so the service will be more effective.

\section{Conclusion}

Sustainable transportation indicators ini this research are used to assess Soekarno Hatta Airport Rail performance. Under utilize environmental friendly public transportation can be have worse impact to environment than the less environmental friendly mode. Soekarno-Hatta Airport rail tends to have environmental degradation and low social equity because it is focus more on economic than to the environment and social aspect. To improve the sustainability in short term can be done by delete the uneffective trips or in another word by implement the demand response scheme. In a long term to increase the sustainability can be done by improve its conectivity by connected infrastructure and feeder transportation. The conectivity should integrate the network, fare and ticketing, information, physical infrastructure, and time schedule.

\section{References}

[1] J. Vespermann and A. Wald, "Intermodal integration in air transportation: Status quo, motives and future developments," J. Transp. Geogr., vol. 19, no. 6, pp. 1187-1197, 2011.

[2] L. Zakowska, "ScienceDirect Multi-criteria evaluation of public transport interchanges," Transp. Res. Procedia, vol. 24, pp. 25-32, 2017.

[3] V. Reis, J. Fabian Meier, G. Pace, and R. Palacin, "Rail and multi-modal transport," Res. Transp. Econ., vol. 41, no. 1, pp. 17-30, 2013.

[4] M. Givoni and D. Banister, "Airline and railway integration," Transp. Policy, vol. 13, pp. 386-397, 2006.

[5] A. Cokasova, "Air-Rail Inter-modality From Passenger Perspective," in Proceedings of the 19th Dresden Conference on Traffic and Transportation Science, 2003, pp. 1-9.

[6] J. Åkerman and M. Höjer, "How much transport can the climate stand?-Sweden on a sustainable path in 2050," Energy Policy, vol. 34, no. 14, pp. 1944-1957, 2006.

[7] L. Li, "the Role of Railways in Sustainable Transport : a Case Study of China," 2014. 